\title{
Models of convicts' labor organization in European German-speaking federative countries: comparative legal research
}

\author{
Alexey V.Rodionov ${ }^{1}$, Andrey P.Skiba ${ }^{1}$,Edgar V.Baljan ${ }^{2}$, \\ Grigorij M. Kalashnikov ${ }^{3}$, Elena A.Buranova ${ }^{1}$ \\ ${ }^{1}$ Academy of Federal Penitentiary Service of Russia, \\ 1, Sennaya ul., Ryazan, 390000, Russian Federation \\ ${ }^{2}$ Center of legal education and implementation of rehabilitation programs \\ of the Republic of Armenia, \\ 3/8, Vazgen Sargsyan ul., Yerevan, 0010, Republic of Armenia \\ ${ }^{3}$ Academy of Management of the Ministry of Internal Affairs of Russia, \\ 8, ul. Zoya and Alexander Kosmodemyanskie, Moscow, 125171, Russian Federation
}

For citation: Rodionov, Alexey V., Skiba, Andrey P., Baljan, Edgar V., Kalashnikov, Grigorij M., Buranova, Elena A. 2019. "Models of convicts" labor organization in European German-speaking federative countries: comparative legal research". Vestnik of Saint Petersburg University. Law 3: 547-556. https://doi.org/10.21638/spbu14.2019.309

This article presents the results of comparative legal research of convict labor organization models in European German-speaking federative countries. The researched group of countries included the Austrian Republic, the Federative Republic of Germany and the Switzerland Confederation. As a base for the comparative research, penal law regulations in the sphere of convict labor organization in the Russian Federation were taken. This choice is explained by the federative form of government in the Russian Federation and the pronounced affiliation of the Russian legal system to the Romano-Germanic legal family that developed over a long period in the researched group of European countries. Sources of legal regulation of convict labor in the Austrian Republic, the Federative Republic of Germany, the Switzerland Confederation and the Russian Federation were determined and analyzed. Scientific research is grounded on the systematic combination of comparative legal and historical research methods. The information base of the study is formed by official statistical data of penitentiary departments of the researched countries, their valid penal legislation, and scientific works of Russian and foreign authors on the researched issue. Peculiarities of the researched countries' penal systems were analyzed. Among such peculiarities we investigated: operators of prison systems, influence of the federative form of state on penal system organization, separate positions of penal legislation, etc. A wide range of aspects of convicts' professional training was researched. Models of convict labor organization of the studied countries were observed, analyzed and compared. We defined the high level of legal regulation of the researched field of public relations in European German-speaking federative countries and in the Russian Federation as well.

Keywords: attraction to labor, penitentiary production, correctional facilities, convicts, penal law.

\section{Introduction}

A comprehensive and quality research of the convicts' labor organization models and justification of effective ways of the existing problems' solving requires a highly directional study of different legal systems and practices in this field. In this case it is advisable

(c) Санкт-Петербургский государственный университет, 2019 
to conduct a complex study, which is worth to be based on the theory and methodology of the classic comparative legal research. In order to provide the complexity of such research we decided to analyze models of convicts' labor organization in European German-speaking federative countries. To the researched group of countries were included Austrian Republic (hereinafter Austria), Federative Republic of Germany (hereinafter FRG) and Switzerland Confederation (hereinafter Switzerland). This work involves analysis of penal legislation of the researched group of countries and their national practices of its application. This in turn determined the usage of specific sociological and historical-legal methods, methods of legal statistics and comparative law. The last method allows searching for effective solutions to existing problems in the national legislation of the researched group of countries that expands the scope and format of the study.

The prison systems of the researched group of countries formed during a long historical period. It is worth to be considered that processes of the prison systems' development of Austria, FRG and Switzerland were the object of close factors of influence. In particular factors of religion, culture, economy and processes of state construction. Close ethnical, lingual, cultural and historical peculiarities of the researched counties resulted in relative law systems and forms of government.

Experience of the prison systems' development in the researched group of countries is worth to be contemplated from the point of view of the development of penal law and national prison systems of the emerging European countries. As the base for the comparative research were taken penal law regulations in the sphere of convicts' labor organization in the Russian Federation. This country was chosen as a base for comparison due to its federative form of government and significant contrast in certain aspects of prison system's performance (in comparison with Austria, FRG and Switzerland).

Prison systems of European German-speaking federative states are among of the most effective in the world, that is proved by the relatively low level of post-penitentiary recidivism and a low number of persons who are currently incarcerated in penitentiary establishments. Austria, FRG and Switzerland have considerable experience in the attraction of convicts to different types of work, that determines the relevance of studying of their experience. The legal status of prisoners and their labor rights in the researched group of countries are regulated and protected on a high level. In this sphere the researched group of countries significantly outperform other highly developed countries of Europe (in particular United Kingdom, France and Italy) and the USA.

\section{Discussion}

Norms of German-speaking federative states' legislation that regulate the usage of prisoners' labor and enforcement activities in this area cause scientific interest and worth to be researched. In the modern legal science, the issues of the method of comparative law application in the sphere of penal public relations have received extensive coverage in the works of Russian scientists (Teplyashin 2011, Shishkanova 2015). The possibilities of effective usage of the comparative law method in contemporary legal studies were investigated in a number of works (Tikhomirov 2015, Amosova, Yurkovskii, Yurkovskaya 2016) The use of comparative law allows us to search for effective solutions to the existing problems in the sources of law of other legal families and countries, which expands the field of research and the format of the search for optimal solutions. 
The problematic of the enforcement of criminal sanctions in Germany and the labor of the inmates of German penal systems' institutions has received considerable development in scientific literature (Tarbagajev, Nazarov 2015, Golovnenkov, Ponyatovskaya 2015). Certain aspects of the imprisonment execution in Austria were illumined in the works of Russian and foreign scientists (Voronin, Vejbert 2014, Paus, Remele 2016, Eher, Schilling, Graf 2006). Penitentiary system of Switzerland was the subject of a number of researches (Wolff, Casillas, Perneger 2016, Wangmo, Hauri, Meyer 2016, Becci, Purdie 2012).

\section{Materials and methods of the research}

The study is based on the use of comparative legal and historical research methods. As information base of the research were used current legal acts of Austria, FRG, Switzerland and the Russian Federation that govern the execution of criminal sanctions, and the organization of labor of the penitentiary institutions' contingent. Data of the Austrian, German, Swiss and Russian state statistics in the field of penitentiary activities was also used. Cross-country comparisons with consideration of the relevant legal norms and regulations of legislation of England, France and the United States were conducted.

\section{Brief description of penitentiary systems}

\subsection{Austria}

Austria is a federal republic that borders on other countries of "The Old Europe", that are similar in form of government, (FRG and Switzerland). Despite significant cultural, linguistic, humanitarian, and other similarities between the federal republics of central Europe, the Austrian penitentiary system has a number of significant differences from the corresponding systems of its closest neighbors. At the same time, in Austrian penal law there are a number of legal institutions that are practically not found in other national legal systems. Suffice is to note the existence of the Law on the execution of administrative punishments (Bundesrecht konsolidiert: Gesamte Rechtsvorschrift für Verwaltungsstrafgesetz (BGBl. Nr. 52/1991) vom 1/31/1991), combining the norms of penal and administrative law and accordingly mediating a whole complex of intersectional relations.

Official statistics indicate a fairly high efficiency of the Austrian penitentiary system. As of June 1, 2016, 8177 people were held in Austrian prisons. At the same time, over the last 10 years, there has been a decrease in the number of convicts in Austrian deprivation of liberty places (8853 people in 2006). Note that in 2016, 93 prisoners accounted per 100 thousand people of population in Austria. That generally corresponds to the statistics of the developed European countries (less than 100 people of prison population per 100 thousand people of population of the country). For Austria, as well as for a number of other European countries at the present stage of development, a rather high proportion of foreign citizens in places of detention (53.3\%) is also a modern characteristic feature. The operator of the Austrian penitentiary system is the Prison Administration, subordinate to the Federal Ministry of Justice. 


\subsection{FRG}

The penitentiary system of Germany is one of the most effective in Europe, as evidenced by the relatively low statistical indicators of the level of post-penitentiary recidivism and the relatively low number of prison population (in terms of the number of prisoners per 1000 population). At the same time, Germany has gained considerable experience in convicts' attraction to labor, while the statistics of the penitentiary systems' acting shows that the methods used to convicts' labor organization are effective and can be qualified as progressive.

The efficiency of the penitentiary system of the FRG and the quality of the labor organization processes of German penitentiaries' contingent can be judged on the basis of statistical data. 62.9 thousand people (2018) served their sentences in German places of imprisonment and 41 thousands of prisoners (62\%) were employed. The most remarkable is that every year a little less than 50 thousand people are released from places of liberty deprivation, which is explained by a rather significant part of the prison population with sentences of one year or less (44\%). The total number of previously convicted persons who have served a sentence of imprisonment in Germany counts 800 thousand people. Level of prisons' occupancy is on the level of $85.2 \%$ (2018).

In our opinion, it is noteworthy that the number of convicts in German prisons until 2015 had a steady downward trend. Thus, in the Federal Land of Hamburg from 2003 to 2010, the number of convicts in prisons decreased by $40 \%$ (Conzac, Chernysheva 2014, 85). These statistics deserve special attention, considering that the population of Germany according to the 2016 census amounted to 81.2 million people. Also notable is the fact, that with a twice smaller population compared to Russia, the FRG is spending comparable funds on its penitentiary systems' functioning ( 4 billion $€$ per year).

Penitentiary system of the FRG fully complies with the federal structure of its state. In Germany, there is no single national operator of the penitentiary system located in the federal center. In fact, the system is represented by 16 local prison administrations, which are subordinate to the ministries of justice of the relevant federal lands and manage 183 institutions.

\subsection{Switzerland}

Swiss penitentiary system is characterized by significant features that distinguish it from its German and Austrian counterparts. The system is centralized and managed by the Federal operator - Section for the execution of sentences and measures of Federal Department of Justice and Police. The Constitution of Switzerland obliges the Cantons to execute sentences of their criminal courts. Specific features of national penal legislation and its practice of application are manifested in the light of a number of geographical and demographic characteristics of individual cantons. The inter-regional differences between cantons in size and population are significant. The area of the smallest Canton (Basel Stadt) differs from the area of the largest (Berne) by 161 times. The population of the smallest Canton (Appenzell Innerrhoden) is smaller in compare with the most populated (Zurich) by 90 times. As a result, not all subjects of the Confederation can afford the creation and maintenance of their own regional penitentiary systems capable for executing all types of punishments for all categories of convicts, taking into account the requirements for the differentiated content of various categories of convicts in diverse modes of 
deprivation of liberty. A separate issue is the economic feasibility of the penal institutions' establishment in the individual cantons. In 2017 on the base of 106 Swiss penitentiary institutions 6863 prisoners served their sentences.

\section{Sources of legal regulation of convicts' labor}

The main sources of law that govern the execution of sentences in Switzerland are the Federal Constitution of the Swiss Confederation, Swiss Criminal code and Swiss Criminal Procedure Code. It is notable that the distinguishing feature of the Swiss legal system (in particular legislation that govern the issues of criminal liability and the execution of sentences), is that institutions of direct democracy play a significant role as sources of law. A number of legal provisions, governing the procedure for the execution of sentences in Switzerland, were adopted on referendums and their results were embodied in articles $123 \mathrm{~A}, 123 \mathrm{~B}, 123 \mathrm{c}$ of Federal Constitution of the Swiss Confederation. Legal norms that govern issues of convicts' labor organization in Switzerland are mainly located in the Swiss criminal code. No particularized law, concerning the issues of criminal sanctions' execution exists in Switzerland.

Labor organization as the basis of prisoners' re-socialization in Germany received normative consolidation in the Federal law of Germany "About execution of penalty in kind of imprisonment, and manifested in the imprisonment measures of correction and safety" from 16.03.1976. The vast majority of the Austrian penal law norms are located in the Criminal code of Austria, Criminal Procedure code of Austria and in the Federal law of Austria "About execution of criminal sanctions" from 26.03.1969.

General provisions concerning the questions of prisoners' labor are placed in the Federal law of Austria "About execution of criminal sanctions" (hereinafter Law of 1969). The purpose of the convicts' involvement to labor activities in FRG is specified in article 37 of the Law "About execution of penalty in kind of imprisonment, and manifested in the imprisonment measures of correction and safety" (hereinafter - the Law of 1976). Sources of German criminal and criminal-procedure law consists no norms, connected with execution of sentences.

Russian penal law is codified and its norms are mainly located in Penal code of the Russian Federation. Some aspects of execution of sentences in the Russian Federation are regulated by provisions of Criminal and Criminal procedure codes.

Swiss legislation doesn't establish any objectives of convicts' employment. Labor of convicts isn't observed as a special mean of correction. Notable that Austrian Law of 1969 contains norms that determine labor as the main source for compensation of convicts' maintenance costs. On the base of the results of the analysis of norms of Austrian criminal, criminal-procedural and penal legislation, we made the conclusion that convicts' labor is observed as the main mean of correction, that must be applied to all categories of prisoners. And in some cases (public works under $\$ 202$ of the Criminal Procedure code of Austria) labor is a mean of the offender's reputation restoring. In Russia there is no regulatory basis for the purposes of the convicts' attraction to labor. And the convicts' labor, according to the Penal code of the Russian Federation, is a mean for correction of convicts - one of the goals of Russian penal legislation. 


\section{Professional training of convicts}

Issues of professional education and training of convicts in Switzerland are regulated by the provisions of article 82 of Swiss Criminal code. Convicted persons are entitled to get education in places of deprivation of liberty, but the condition of educational programs passing is the professional convict's suitability and availability for the organization of educational process in institutions or abroad (in accordance with the characteristics of different modes of punishment in form of freedom deprivation). If convicted person instead of undergoing vocational training is passing through any other educational program in accordance with his individual plan of serving the sentence, he is supposed to get remuneration. It is notable, that in Switzerland, sentencing is usually executed according to individual for every convict plan of correction. That is why Swiss convict receive remuneration not for educational activity. He receives it for his disciplined passing through the road map, described in his individual correctional plan.

Certain range of aspects of convicts' professional education in Austria are regulated by $\$ 48$ of the Law of 1969. All convicts who don’t have profession or appropriate education that allows acting a qualified work are entitled to receive professional education, depending on currently available opportunities of correctional facilities. Education documents must be framed without any evidence that they were obtained in the course of serving the sentence of imprisonment in a penal institution. In the account of working hours, Austrian convicts may be allowed to participate in educational program or courses outside the institution. Such right may be exercised regarding those convicts in respect of whom there is no fear that they will exacerbate this right. In this case, the prisoner will get remuneration in the amount of the average wage of a convict in this prison.

Work and vocational education, according to German legislation are expected to cultivate convicts' special skills and knowledge in order to enable them to find a satisfactory paid job after release. The administration of the penitentiary institution in Germany is obliged to find for the prisoner economically gainful employment, taking into account his skills, abilities and knowledge. Notable that Austrian Law of 1969 contains norms that determine labor as the main source for compensation of convicts' maintenance costs. Convict's labor isn't determined as a mean for the employment provision after release of the prisoner in Austria

All prisoners in FRG should have the opportunity and conditions for learning and training. In a situation where the prisoner cannot be given the above work, or an opportunity for vocational education, the administration of the penitentiary institution is obliged to create conditions for other suitable classes. When a prisoner is unable to do the work, he should be provided with another suitable form of employment. According to Swiss penal legislation prisoners are to be involved in labor activity and education only in case of appropriate conditions' availability.

Convicted prisoners in FRG are allowed (have the right) to receive or complete their secondary education. In German correctional facilities must be provided training according with the school curriculum or the program of special (correctional) school. The same applies to vocational training. The learning process should take place during working hours.

In Russian prison authorities are obliged to involve convicts to different types of work taking into account their gender, age, disability, health status, and if it is possible, specialty. 
But the main basic condition is the availability of job places, in accordance with part 1 of article 103 of PCRF

\section{Models of convicts' labor organization}

Public works in the Austrian legislation are considered as an interbranch criminal, criminal procedural, penal and administrative legal institution. This punishment can be imposed by attorney in case of termination of criminal prosecution ( $\$ 198$ of Criminal Procedure code of Austria) in respect of a person under certain conditions ( $\$ 200$ of Criminal Procedure code of Austria):

1. The crime has not led to the death of victims (including relatives of victims as a consequence of their severe mental and/or emotional stress).

2. The offender pleaded his guilt and agreed to serve the public work.

3. Public works appropriately compensate for the damage caused and are in line with the severity of the crime.

According to $\$ 202$ of Criminal Procedure code of Austria, Public works can’t exceed more than 8 hours a day and 40 hours a week. It is unacceptable to appoint public works, which can inadmissibly infringe the rights of the convicted person and/or his lifestyle. On our opinion, in this case Austrian legislator considers culture, lifestyle and religious feelings of certain ethnic, national and social community groups. The order of public works' serving is regulated by $\$ \$ 3,3 \mathrm{~A}$ of the Law of 1969. In accordance with the provisions of this law, public works are executed in favor of organizations or institutions that have agreed to employ the convict. Such agreements are to be concluded between state authorities of the Federal Lands and specific bodies and institutions, which can potentially employ offenders. In a situation when can take place the replacement of the unserved part of public works by imprisonment conversely, the offset of the timing occurs at the rate of 4 hours of community service for 1 day of imprisonment ( $\$ 3 \mathrm{~A}$ of the Law of 1969). It is also indicated that public works should not interfere with professional activities and/or study of the convict. Public works can also be appointed by the court as a replacement of the unserved part of the deprivation of liberty for up to 9 months.

Wide range of aspects of convicts' labor organization in Switzerland is regulated in articles 37, 81, 83, 107, 375 of the Swiss Criminal Code. Prisoners in Switzerland are obliged to work. Wherever possible, inmates should be given work according to their skills, experience, education and interests. With the consent of the convict, he may be employed by the private employer. Note that unresolved is the question of the subject of the organization of production in penal institutions. Also undertrained is the question of the job places location, created by private employers in prisons or outside of them. Offenders may also be attracted to work during the execution of the penalty in the form of community service. This type of sentence can be assigned instead of a fine but in the amount of not more than 360 hours. The entire volume of community service must be performed for not more than one year. In case of violation, the convicted person must pay increased compared to the initial amount of the penalty (article 107 of the Swiss Criminal Code). Cantons are responsible for the execution of sentences in the form of community service. The authorized officials of the Cantons determine the nature of community work and forms of employment of convicts. If community services are assigned as an alternative to imprison- 
ment, their volume should not exceed 720 hours (article 37 of the Swiss Criminal Code). Community service can be applied as alternative punishment to imprisonment for a term not exceeding 6 months. Usually 4 hours of community service replace one day of imprisonment. It should be noted that the duration of assigned to acting community service can be increased during their execution, depending on the quality of convicts' performance of his duties (section 2, article 375 of the Swiss Criminal Code).

In FRG was implemented and currently is used classic Oborn prison system. Prisoners are held in solitary confinement at night, and in daytime they work in groups (articles 17 and 18 of the Law of 1976). Prisoners are to be transferred from solitary confinement and further kept with other convicts only in case they need help or their life and health are threatened. Labor activity of convicted prisoners is organized with the consideration of their group work and joint activities. Restrictions on labor of prisoners in group can be the following: when a prisoner may have a detrimental effect on others; when a prisoner is on probation; to ensure order and security in the institution; at the request of the prisoner.

In German correctional facilities of the open type prisoners can be held together at night, but if it will not interfere with the security and adversely impact of some prisoners on others. In Russia, the transfer of the sentenced personer from the so-called "closed" to "open" facility (for example, from a correctional colony of common regime to a settlement colony), can be performed only according to the court decision in accordance with the article 78 of Penal Code of the Russian Federation and articles 397, 399 of the Criminal procedure code of the Russian Federation.

German prisoners may provide themselves with work independently. At the same time, articles 11 and 39 of the Law of 1976, allow the convicts to be engaged in labor activity outside the institution. Such measures are considered to be a kind of promotion and are used to check the convicted person in the context of his willingness to work normally on the freedom. The mitigation measures of the regime are applied in relation to prisoners, who with high probability will not be allowed to abuse the exemptions and would not commit new crimes. Self-employment is permitted only if the earnings of the convict are enough to compensate costs of his maintenance in detention (paragraph 2 of article 39 and paragraph 4 of article 50 of the Law of 1976)

The convicts' labor in German prisons is obligatory according to paragraph 1 of article 41 of the Law of 1976 (the same conditions are provided by paragraph 1 of the article 103 of the Penal Code of the Russian Federation) and the passage of the educational program is carried out only with the consent of the convicted person (paragraph 2 of the article 41 and paragraph 3 of the article 37 of the Law of 1976). However, German legislators didn't provide state authorities with disciplinary measures on the case of the convicts refusing to start working (unlike Russian, English and American law, where labor is also required; at the same time in Russia the refuse of the convict from work is considered to be a willful violation and may be determined as the basis for the change of the type of the penitentiary in the direction of tightening of the conditions of serving the punishment according to the court sentence (articles 78, 116 of the Penal Code of the Russian Federation and articles 397, 399 of the Criminal procedure code of the Russian Federation).

Prisoners in FRG can be engaged to perform household chores in the institution for a period of three months during a year (1/4 of the working time). At the request of the convicted person the length of this type of work can be increased. Convicts older than 
65 years, pregnant women and women with children (until they reach full earning capacity) are released from the performance of household chores.

German prisoners also have a number of employment safeguards. Convicts, who worked during a calendar year, can receive up to 18 days of release from work in the new calendar year. In this case days of the work release can be taken at any time and in any amount (article 42 of the Law of 1976).

\section{Conclusion}

The results of the analysis of the regulatory framework, practice and experience of convicts' labor organization in European German-speaking federative countries provide us with opportunity to articulate a number of general derivations.

1. Special contingent of the penitentiary institutions in European German-speaking federative countries has a wide list of legislated labor rights, which determines the relatively more favorable legal status of convicted prisoners there in comparison with several other developed countries. In FRG and in Austria such regulations are more detailed. In Switzerland, labor guaranties of convicts are less regulated and mainly are established by legal practice and became a result of high legal culture of society. Notable that in the USA, United Kingdom and France the labor rights of convicted prisoners are protected in a much lesser extent.

2. The process of organization of convicts' labor in Austria and FRG has received considerable attention. Labor is observed as the main mean of correction and reeducation of convicted persons. Labor also plays a great role in the coverage of the sentencing costs. Thus, the production process is organized in accordance with the requirements of maximizing the productivity and profitability of economic activities that largely determines the approach of the working conditions in prisons to the conditions of private enterprises on which convicts will have to work after the release. Achievement of the results in the outlined fields greatly depends on the effectiveness of close cooperation of penitentiary facilities with huge productive enterprises, which provide payable demand and concrete orders, capital funds and fixed assets, manufacturing technology and appropriate experience.

3. Labor is a mandatory requirement for prisoners in all analyzed penitentiary systems. Deserves attention the fact that the main German legislative act regulating the process of execution of punishment in form of imprisonment (Law of 1976) does not contain guidance on the application of disciplinary measures for those convicts who refused from the labor activity (unlike English and American law, where labor is also required). In Austria, prisoners who refused to work are the object of monetary sanctions. Any discipline measures in Austria in the researched sphere are not applicable.

4. Highly productive labor of convicts in the researched countries makes it possible to provide a relatively high level of costs' coverage of the prisoners' maintenance. Along with a low level of recidivist it indicates the formation of sustainable employment and professional competences of the released prisoners. Notable that during a long time more than a half of all prisoners are presented by foreign citizens. Efficiency of applicable correctional measures for native citizens can be evaluated as rather high. 


\section{References}

Amosova, T. V., A. V. Iurkovskii, E. A. Iurkovskaia. 2016. "Convergence and legal linguistic methods in comparative law: legal comparative linguistics”. Voprosy rossiiskogo i mezhdunarodnogo prava 9: 96-107. (In Russian)

Becci, I., M.Purdie. 2012. "Gendered religion in prison? Comparing imprisoned men and women's expressed religiosity in Switzerland." Womens studies-an interdisciplinary journal, vol. 41, iss. 6: 706-727.

Eher, R., F. Schilling, T. Graf. 2006. "Comprehensive assessment of sexual offenders in Austria’s prison system." Neuropsychiatrie, vol. 20, iss. 1: 50-56.

Golovnenkov, P. V., T. G. Poniatovskaia. 2015. "Property confiscation in Russian and German Criminal Law". Kriminologicheskii zhurnal Baikal'skogo gosudarstvennogo universiteta ekonomiki i prava, vol. 9, no. 1: 164-173. (In Russian)

Paus B., Remele E.Prison. 2013. "Culture Habitus and Custody in an Austrian Prison." Monatsschrift fur Kriminologie und Strafrechtsreform, vol. 96, iss. 1: 30-46.

Shishkanova, I. A. 2015. "Comparative jurisprudence in dissertation researches (on the example of criminal and executive subject)". Ugolovno-ispolnitel'noe pravo 19 (1): 73-76. (In Russian)

Tepliashin, P. V. 2011. "The method of comparative law as a tool to harmonize the modern penal law of Russia". Sovremennoe pravo 8: 39-42. (In Russian)

Tarbagaev, A. N., A. D. Nazarov. 2015. "Judicial supervision and the issues of crime and offense prevention in the criminal procedure of Russia and Germany". Kriminologicheskii zhurnal Baikal'skogo gosudarstvennogo universiteta ekonomiki i prava, vol. 9, no. 3: 560-570. (In Russian)

Tikhomirov, Iu. A. 2015. "New evaluation measures in comparative law". Zhurnal zarubezhnogo zakonodatel'stva i sravnitel'nogo pravovedeniia, vol. 1, iss. 5: 733-728. (In Russian)

Voronin, Iu.A., S.I. Veibert. 2014. "On some prospects of criminal policy harmonization in terms of legal consequences of crime”. Kriminologicheskii zhurnal Baikal'skogo gosudarstvennogo universiteta ekonomiki i prava 3: 145-155. (In Russian)

Wolff, H., A. Casillas, T. Perneger. 2016. "Prison overcrowding and the risk of self-harm in a pre-trial detention setting in Geneva, Switzerland”. Journal of general internal medicine, vol. 31, iss. 2: 369-370.

Wolff, H., A. Casillas, T. Perneger. 2016. "Self-harm and overcrowding among prisoners in Geneva, Switzerland". International journal of prisoner health, vol. 12, iss. 1: 39-44.

Wangmo, T., S. Hauri, A. Meyer. 2016. "Patterns of older and younger prisoners' primary healthcare utilization in Switzerland”. International journal of prisoner health, vol. 12, iss. 3: 173-184.

Received: January 16, 2018

Accepted: May 17, 2019

\section{Author's information:}

Alexey V. Rodionov - Dr. Sci. in Economy; avrpost@bk.ru

Andrey P. Skiba - Dr. Sci. in Law, associate professor; apskiba@mail.ru

Edgar V. Baljan — PhD in Economy; balyan86@mail.ru

Grigorij M. Kalashnikov - PhD in Economy, associate professor; mrgriga@ya.ru

Elena A. Buranova - PhD in Economy, associate professor; buranova_ea@mail.ru 